\title{
A study on innovativeness and regulating conflicts between the fishers and farmers in the Balua wetland
}

\author{
R.K. Mehta ${ }^{1}$, S.N. Ojha ${ }^{1 *}$, Vinod $\operatorname{Yadav}^{1}$, S.C. Rai ${ }^{2}$, Shivendra Kumar ${ }^{2,3}$ \\ ${ }^{1}$ Fisheries Economics, Extension and Statistics Division, Central Institute of Fisheries Education (CIFE), Mumbai - \\ 400 061, INDIA \\ ${ }^{2}$ College of Fisheries, Dholi, Rajendra Agricultural University, Muzaffarpur - 843121 (Bihar), INDIA \\ ${ }^{2,3}$ Krishi Vigyan Kendra, Rajendra Agricultural University, Madhopur - 845454, West Champaran, Bihar, INDIA \\ *Corresponding author. E-mail: snojha@cife.edu.in
}

Received: October 26, 2015; Revised received: March 17, 2016; Accepted: June 3, 2016

\begin{abstract}
Wetlands store ground and surface water even when the rainfall is erratic. However, the rising demand for water and land to sustain the ever increasing population has manifested in many kinds of conflicts in wetlands. In the study area, Balua Chaur (wetland) in Bihar state of India, 16 conflicts emerged when the flooded lands of farmers was accessed by the fishers to fish. Such conflicts had further marginalized the already indigent fishers. Factor analysis, to reduce the socioeconomic and psychological variables of the fishers that were associated with innovativeness and further analysis of ANOVA and regression was used. In case of fishers, two major groups of interrelated variables that accounted for $60.6 \%$ of the total variance were identified through this method. Factor 1 accounted for $34.8 \%$ of the total variance that included innovativeness, income, education, mass media exposure, extension contact, livestock ownership, land ownership, mobile use collaborating and competing style of conflict management and named as innovative factors. The ANOVA table and stepwise multiple regression model exhibited that the nuclear family type and livestock have significant impact on the innovativeness of fishers with $R^{2}$ value 0.255. In this paper, peace and prosperity model based upon the analysis of primary information collected from the fishers, farmers and key informants is proposed to foster innovativeness to enhance the productivity of wetland and resolve conflict to mobilize the resources in efficient and judicial manner.
\end{abstract}

Keywords: Conflicts, Factor analysis, India, Innovativeness, Wetlands

\section{INTRODUCTION}

Wetlands in the form of marsh, fen, peatland or water; natural or artificial; permanent or temporary, with static or flowing water that is fresh or brackish or salty, and which in the areas of marine water has a depth, at low tide, not exceed six meters are estimated in the world to be 2060 covering 197 million hectares (Ramsar Convention Secretariat, 2013). However, Moore (2008) suggested that a single definition would not justify the diversity of wetlands existing in the world. Wetlands in India that occupy 58.2 million hectares out of 305 million hectares of the total reported area frequently exist near rivers, like, Ganga, Brahmaputra, Narmada, Godavari, Krishna, Kaveri, and Tapti (Prasad et al., 2002). In such wetlands farmers outstrip fishers in terms of technology adoption and therefore fisheries technologies need to be transferred in wetlands to give the latter a competitive edge. Fisheries interventions in the floodplain can be through different methods like: " installation of low-cost large meshed bamboo fencing at water inlet and outlet points and setting of ring culverts for maintaining suitable levels of water for fish culture without hampering the production of rice in the upland areas of the floodplains; stocking of larger fingerlings at suitable stocking densities of indigenous (rohu, catla, mrigal) and exotic (silver carp, bighead carp, common carp/mirror carp) species at $31-48 \mathrm{~kg} / \mathrm{ha}$; post stocking management, use of extra fencing during over flooding and mobile guarding by using boats; harvest management, regulations in harvest for certain period, and use of multiple harvesting techniques" (Rahman et al., 2010). Conflict is a situation where two parties with different point of the views believe that the other party will have or is having the intention of taking an action against them and there is need to resolve it. However, conflicts also become the means to foster innovation where competitiveness exists (Baqutayan, 2014). Conflicts remain a common issue in wetlands too as the water level fluctuates in different seasons and alters the dimensions of owned- farmlands. Thus, there is a need to highlight the conflicts in wetlands, to recognize the processes of resolution of conflicts, and identify agencies that are involved in conflict resolution (Panini, 2007).

Conflicts in the wetlands are mostly due to the common resources that are used by both farmers and fish- 
ers (Bhuiyan, 2013), reduction in wetland surface, urban and infrastructure development (Sebastiá-Frasquet et al., 2014), increased commercial use of the ecosystem, differential perspective for landscape planning, lack of property rights demarcation, conservation and livelihood approaches lack of coordination between line departments (Arsad, 2011), competition among fishing gears, conflict of interest between the lease holder and the community and lack of public awareness on the need of wetlands protection (Wang et al., 2008). In order to resolve such conflicts, and for long term sustainability in resource management, the suggested strides may be, encouraging power sharing between the state and stakeholders (Khan, 2011), promoting local participation in managing common resources (Kothari, 2011), developing a 'tailor fit approach' for different wetlands (Cunningham et al., 2011), and finally designing a comprehensive institutional structure for wetlands management.

The research questions of the study were raised as: what are the conflict management styles of primary stakeholders residing on the wetland? To what extent they are able to manage conflict locally? What will be the strategy to manage unresolved conflict? Accordingly, this study was conducted to: understand the conflict management styles of the fishers and farmers dwelling on the wetland; assess the extent of conflicts resolved through the existing conflict management systems; and propose conflict and innovativeness management strategies for the fishers and farmers. The upshot of this study manifested into an innovative peace and prosperity model that can address the issues related to adoption of new technology and reinforce the local conflict resolution mechanisms and enhance the productivity of wetland in judicial, sustainable, effective and efficient manner.

\section{MATERIALS AND METHODS}

Study framework: The present study, carried out in 2013 , in the wetland situated in the Gangatic plains on North India. The study area was identified by taking into account the population of fishers. In North India, the state of Bihar has a large number of inland fishers dwelling in flood prone areas near large numbers of small tributaries of river Ganges.

In this state, two districts, Muzaffarpur $\left(25^{\circ} 53^{\prime}\right.$ to $26^{0}$ $23^{\prime}$ North latitudes and $84^{\circ} 52^{\prime}$ to $85^{\circ} 45^{\prime}$ East longitudes) and Samastipur $\left(25^{0} 27^{\prime}\right.$ to $26^{0} 05^{\prime}$ North latitudes and $85^{\circ} 31^{\prime}$ to $86^{\circ} 23^{\prime}$ East longitudes) were chosen because these are among the top ten districts that have the largest fisher population and fishery resources in India. As the present study's focus was on conflict management, key informants were approached to identify a wetland in these districts where conflicts were very prominent. Accordingly, a wetland (Balua Chaur), in between Muzaffarpur and Samastipur, near a tributary (Gandak river) of the Ganges, was deliberately selected for this study.
Study site: The farmers in the selected study site in Balua Chaur (about 81 ha) mostly cultivated rice $(\geq$ $\left.500 \mathrm{~kg} \mathrm{ha}^{-1} \mathrm{yr}^{-1}\right)$ and wheat $(\geq 2000 \mathrm{~kg}$ ha $-1 \mathrm{yr}-1$, while the fishers caught fish from the water bodies of the wetlands. During flood, fishers also leased in the farmers' flooded lands to catch fish. Also, although the physical and chemical parameters of Balua wetland were found to be suitable for aquaculture (Shweta and Srivastava, 2013), such practices were rarely adopted by the fishers, because of poor fisheries extension services in that area.

There are five villages around the Balua Chaur, out of which, four are in Muzaffarpur and one is in Samistipur. The livelihood of around 150 farm families and 110 fisher families are dependent on this wetland. It was also observed that most of the fishers were dwelling in the village in Samastipur district. Since equal sample sizes help to mitigate the effect of unequal population variances, the best course was to keep the sample sizes as equal. Hence, for this study 40 farmers and 40 fishers, who had experienced floods and conflict in the past five years, were purposely selected from lists of farmers and fishers obtained from these districts. This also ensured that both the groups got equal opportunity to voice their concerns. In addition to these, 20 key informants from community and government organizations were also selected for they could provide an overview of the wetland in terms of conflict management, training and organization development, and also contribute significantly in finding out the nature and type of conflict that emerge between the farmers and fishers mainly in such low lying flood lands.

Identification of conflicting issues from the key informants: KI surveys have also been described as an alternative to population-based studies in evaluating community (Muhit et al., 2007). Thus, in the study area, KIs, who knew much about the conflicts in the floodplains, were identified after consulting community and opinion leaders in the villages, and the extension professionals. Face-to-face and semi-structured interviews were conducted with each of such selected KIs. This was needed as conflicting issues can sometimes be sensitive and have to be expressed properly so as to get an effective response during the survey. The KIs spelt out sixteen conflicting issues in that wetland (Fig 1). They also estimated the extent of such conflicts in terms of percentage. It was perceived by the KIs that 100 percent fishers raised 13 out of the 16 conflicting issues, 100 percent farmers were observed to raise 8 out of 16 conflicting issues. This clearly revealed that fishers were more deprived than farmers.

The next step was to generate suggestions on resolving the conflicting issues. Therefore, the informal (opinion leaders) and the formal KIs were encouraged to ponder on conflict resolution strategies (Table 1). Furthermore, interviewing KIs from a wide range helped in gathering varying perspectives on the issue. All the 
formal KIs, who were local officials and had witnessed the conflicts over the years felt that, basically farmers and fishers lacked the knowledge about modern technologies and so they were idle and unsafe (Alika and Aibieyi, 2014). Therefore, proper training and input support could lower down the level of conflicts. Based upon this wisdom of the KIs, a scale to determine the innovativeness of the fishers and farmers was introduced in the survey, so as to know the readiness of the community to accept new technology. The other strategy suggested was government intervention in the decision making for formalizing negotiation during the sharing of the profit from the fish harvested from the flooded lands of the farmers. Lastly, the KIs emphasized on points like, community empowerment through community based farming, strengthening of cooperatives and SHGs, and encouraging NGOs in this empowerment process. Though, KIs provide insight on sensitive issues related to conflicts and help in exploring new ideas while formulating the conflict resolution strategies relevant for the selected wetland, they provide a very limited basis for quantification . Moreover, when only KIs were interviewed, it was difficult to imagine how the community would be mobilized to get better training, resolve conflicts and get organized.

Data collection: In the study area, 40 farmers and 40 fishers, who had experienced flood and conflict in the past five years, were randomly selected from lists of farmers and fishers obtained from these districts. The respondents were interviewed with a structured schedule. The scales for the measurement of innovativeness developed by Hurt, H. T., Joseph, K., and Cook, C. D (1977) was used in this study to find out the readiness of the respondents to adopt new technology. Additionally, the respondents' preferences in choosing persons to collect new information, and the socioeconomic factors influencing them were also collected to further explore their profiles and their relationship with innovativeness.

The tool to quantify 'Conflict Management Styles' developed by Reginald Adkins (2006) was used in this study of different conflict management styles of fishers and farmers. It was assumed that reduced level of conflicts might help in better transfer of technology. Therefore, conflict management styles of innovative farmers and fishers were determined to select appropriate beneficiaries of the extension programmes. These styles were: avoiding, where respondent was ready to escape from conflicts; harmonizing, where the respondent was ready to lose to accommodate other conflicting party; compromising, where the respondent was ready to lose something, if the conflicting party was also ready to do so; competing, where the respondent was ready to gain even when the conflicting party was losing; and collaborating, when both the parties were gaining mutually. Further, the respondents were asked about the conflict resolution mechanisms. They were individually asked to delineate the conflicting issues that were decided through the courts from those that were resolved locally. In case of the latter, they were also asked to state their preferences for selecting a mediator in the villages, such as elected village leaders or non-elected elderly persons in the villages. They were further requested to express the reasons (like- physical proximity, trust, power, assertiveness, and humility) for preferring such local mediators.

Statistical analysis

Factor analysis: Factor analysis is a data reduction statistical technique which is used to short out the significant data from the large set of data. The variables that loaded under factor one shows maximum variance among was the several factors and second factor causes second most variance and so on. The parameters loaded under the factor are associated with each other and highly disassociated with the parameters loaded in others factor. It was used separately for fishers and farmers, to depict component matrix of the factor loading for each variable onto each factor. This matrix contains the variables calculated after rotation. Factor loadings less than 0.5 were suppressed. The variables of the factor loadings were sorted by size. The option of having only two factors was selected. Factor one seemed to be related to innovativeness. Therefore, it was nominated as innovativeness factors. Accordingly, factor two seemed to be non-innovative factor. The innovative factors were observed to be different for the farmers. It further helps in the extraction of date for other statistical analysis like ANOVA and regression model.

ANOVA and regression analysis: ANOVA and regression analysis was used to investigate the predictor variables that cause significant variance to the dependent variable. Therefore, to predict the innovativeness of fishers, the cumulative influence of the relevant variables identified through stepwise multiple regressions was done. This model helped in selecting the innovative fishers for different extension programmes. In this model the $\mathrm{R}^{2}$ and the $\mathrm{F}$ value for the ANOVA was also seen. These methodologies were used to identify the source of pollutants in Sukhnag stream (Bhat et al., 2014).

\section{RESULTS AND DISCUSSION}

Innovativeness of fishers and farmers: Fig. 2 depicts the innovativeness of fishers and farmers through box plot. In the case of fishers the median was 8 , whereas, in the case of farmers it was 10. This depicted that fishers were also innovative and were ready to accept new technologies. Some fishers were very innovative and had adopted aquaculture practices. While some fishers had lost all hope in fisheries, perhaps because of rising conflicts in the wetland. If the outliers are ignored, the whiskers depicted that the fishers were relatively at the higher range when compared to farmers. The inter-quartile range for fishers was observed to be between 8 and 10 , whereas, the same for the farmers was between 5 and 12 . 
Fig. 3 reveals that most of the fishers found the input suppliers (private net suppliers) and progressive fishers (community) to be more credible sources of information. On the contrary, farmers were having access to public extension services. Although it is accepted that the "government extension programs, extension services of the national agricultural research system, cooperatives, and nongovernmental extension programs have a very limited outreach" (NSSO, 2005), in case of fisheries the situation was especially miserable. Therefore, government institutions in fisheries research and extension agencies should take urgent steps to establish extension services at reduced cost to enhance the access to quality information and extension-contact to fishers (Ifejika, 2013). In the absence of public extension services in aquaculture, progressive fishers may be encouraged to initiate community based fisheries management through Fishers Friend and Fishers Field School programmes of the government.

Conflict management styles of fishers and farmers: Fig. 4 reveals the average score of the five conflict management styles of fishers and farmers. When fishers' score was arranged in ascending order, it was observed that they had highest score in harmonizing style of conflict management, followed by avoiding, compromising, collaborating and competing styles. Moreover, the fishers had scored more than the farmers in harmonizing, avoiding and compromising styles of conflict management, whereas, farmers had scored more in collaborative and competing styles. This could be because the fishers were accommodating in nature as they were dwelling on common resources. Under these circumstances the collaborative farmers, if provided a lead in the village meetings, may support those programmes and technologies that may benefit both farmers and fishers.

Fig. 5 depicts some conflicts that were very severe and were resolved through court. Against this backdrop, it could be difficult to adopt new technologies in wetland fisheries. It was observed that poisoning and poaching were resolved mostly through court whereas uncontrolled grazing and stealing fodders were only sometimes decided in the courts. Other than these four issues most of the conflicts were resolved at local level. To resolve the conflicts at the local level, mediators recognized by the fishers and farmers were enlisted. In addition, the reasons for preference of such mediators were also recorded. Indian villages generally have Panchayats as local self-government headed by Mukhiya and Sarpanch. Mukhiyas have financial powers, whereas, Sarpanchs have judicial powers of minor nature. Table 2 reveals that the fishers customarily approached Sarpanch to resolve their conflicts besides approaching the elderly persons and Mukhiyas; whereas, the farmers preferred the elderly persons over Mukhiya and Sarpach. This could be because Mukhiya and Sarpach of the study area were close to fishers' community. However, the opinions of the elderly persons were acknowledged by both the communities. As such, it is recommended that the elderly persons can be directly involved in the development initiatives (Tait, 2007).

Innovativeness and conflict management styles: Table 3 depicts the results of factor analysis socioeconomic and psychological variables of the fishers and the farmers. In case of fishers, two major groups of interrelated variables that accounted for $60.6 \%$ of the total variance were identified through this method.

In this analysis, factor 1 accounted for $34.8 \%$ of the total variance. This included innovativeness, income, education, mass media exposure, extension contact, livestock ownership, land ownership, and mobile use. This factor also included collaborating and competing style of conflict management. Factor 1 can be interpreted as the innovative characteristic of fishers. Factor 2 accounted for $25.8 \%$ of the total variance and reflected caste, age, family size, credit orientation, and family type; and, thus, factor 2 can be inferred as noninnovative characteristics of fishers.

In case of farmers, two major groups of interrelated variables were identified in the factor analysis that accounted for $44 \%$ of the total variance. Factor 1 , that accounted for $22.6 \%$ of the total variance, included use of mobile, livestock ownership, harmonizing, extension contact, innovativeness, credit orientation, land ownership, income, and mass media exposure, which are the characteristics of innovative farmers. Accordingly, factor 1 can be deduced as the innovative characteristic of farmers. Factor 2 accounted for 21.4 $\%$ of the total variance, and revealed age, family size, and family type, and, hence, the factor 2 can be inferred as non-innovative characteristics of farmers. The innovative fishers were also observed to be more compromising, competing and had higher education level. Such classification of fishers and farmers will help in selecting the potential adopters in field extension programme.

To predict the innovativeness of fishers, the cumulative influence of the relevant variables identified through stepwise multiple regressions were used (Table 4). This model may help in selecting the innovative fishers in different extension programmes. In this model $\mathrm{R}^{2}$ was observed to be 0.25 and the $\mathrm{f}$ value for the ANOVA was found to be significant. Among the independent variables, livestock ownership and family type were observed to have influence on innovativeness of fishers. Therefore, in the beginning, fishers having livestock and living in nuclear families need to be selected for such programmes in order to create a demonstration effect on other fishers.

The above results helped in developing the road map for bringing peace and prosperity in the wetland under study. Fig 6 depicts that model for wise use of wetlands. This model is based on the statistical analysis of responses obtained from fishers, farmers and the KIs in the study area. In this model, firstly, the Department of Fisheries in partnership with NGO may select innovative fishers, who belong to nuclear families and have 
Table 1. Conflict resolution strategies suggested by the key informants

\begin{tabular}{|c|c|c|c|c|}
\hline & Opinions & $\begin{array}{l}\text { Opinion Lead- } \\
\text { ers } \\
(\text { Fishers }) \\
(\mathrm{n}=9)\end{array}$ & $\begin{array}{l}\text { Opinion Leaders } \\
\text { (Farmers) } \\
(n=12)\end{array}$ & $\begin{array}{l}\text { Formal Key } \\
\text { informants } \\
(\mathbf{n}=20)\end{array}$ \\
\hline & Training on technology & & & \\
\hline 1. & $\begin{array}{l}\text { TRAINING AND INPUT SUPPORT } \\
\text { Training in conflict resolution }\end{array}$ & ++ & ++++ & ++++ \\
\hline 2. & $\begin{array}{l}\text { GOVERNMENT INTERVENTION FOR FORMALIZA- } \\
\text { TION OF NEGOTIATION }\end{array}$ & ++++ & ++++ & ++++ \\
\hline 4. & $\begin{array}{l}\text { PREFERENCE TO OUTSIDER CONTRACTOR } \\
\text { Training on community empowerment }\end{array}$ & - & ++++ & ++ \\
\hline 5. & COMMUNITY BASED FARMING & ++++ & ++++ & ++++ \\
\hline 6. & STRENGTHENING COOPERATIVES AND SHGs & ++++ & ++++ & ++++ \\
\hline 8. & $\begin{array}{l}\text { NGO INTERVENTION IN COMMUNITY EMPOWER- } \\
\text { MENT }\end{array}$ & - & - & + \\
\hline
\end{tabular}

$$
\text { Note: }+=5-25 \%,++=26-50 \%,+++=51-75 \%,++++=76-100 \%
$$

Table 2. Reasons of the fishers and farmers to contact local leaders to resolve conflict

\begin{tabular}{llllllll}
\hline $\begin{array}{l}\text { Preferred causes } \\
\text { for accessing }\end{array}$ & \multicolumn{2}{l}{ Fishers accessing preference (\%) } & \multicolumn{2}{c}{ Farmers accessing preference (\%) } & Average (\%) \\
& Sarpanch & Elderly & Mukhiya & Elderly & Mukhiya & Sarpanch & \\
\hline Physical proximity & 100 & 77.5 & 100 & 100 & 100 & 100 & 96.25 (I) \\
Power & 100 & 55 & 97.5 & 25 & 100 & 100 & 79.58 (II) \\
Trust & 75 & 97.5 & 72.5 & 100 & 60 & 24.5 & 71.58 (III) \\
Assertiveness & 70 & 97.5 & 65 & 100 & 42.5 & 5 & 63.33 (IV) \\
Humility & 70 & 92.5 & 20 & 100 & 37.5 & 15 & 55.83 (V) \\
AVERAGE \% & 82.92 (I) & 78.75 (II) & 63.33 (III) & 87.50 (I) & 56.67 (II) & 41.58 (III) & \\
\hline
\end{tabular}

Table 3. Factor analysis of socioeconomic and psychological variables for fishers and farmers: two factor model.

\begin{tabular}{|c|c|c|c|c|c|}
\hline \multicolumn{6}{|l|}{ Component Matrix } \\
\hline Variables & Factor 1 & Factor 2 & Variables & Factor 1 & Factor 2 \\
\hline Innovativeness & 0.535 & -.542 & Use of Mobile & 0.517 & \\
\hline Income & 0.652 & -.505 & Livestock ownership & 0.520 & \\
\hline Collaborating & 0.699 & & Harmonizing & -0.521 & \\
\hline Competing & 0.745 & & Extension Contact & 0.547 & \\
\hline Education & 0.772 & & Innovativeness & 0.681 & \\
\hline Mass media exposure & 0.798 & & Credit Orientation & 0.719 & \\
\hline Extension Contact & 0.831 & & Land ownership & 0.750 & \\
\hline Livestock ownership & 0.832 & & Income & 0.756 & \\
\hline Land ownership & 0.834 & & Mass Media Exposure & 0.806 & \\
\hline Mobile use & 0.838 & & Age & & .646 \\
\hline Caste & & 0.51 & Family size & & .756 \\
\hline Avoiding & & 0.559 & Family type & & .758 \\
\hline Age & & 0.581 & & & \\
\hline Family size & & 0.599 & & & \\
\hline Credit Orientation & & 0.633 & & & \\
\hline Family type & & 0.658 & & & \\
\hline Variance explained (\%) & $34.8 \%$ & $25.8 \%$ & Variance explained (\%) & $22.6 \%$ & $21.4 \%$ \\
\hline Total common varience & $60.6 \%$ & & Total common varience & $44 \%$ & \\
\hline Factor interpretation & Innovative & $\begin{array}{l}\text { Non- } \\
\text { innovative }\end{array}$ & Factor interpretation & Innovative & $\begin{array}{l}\text { Non- } \\
\text { innovative }\end{array}$ \\
\hline \multicolumn{6}{|c|}{$\begin{array}{l}\text { Extraction Method: Principal Component Analysis. } \\
\text { a. } 2 \text { components extracted. }\end{array}$} \\
\hline \multicolumn{3}{|c|}{$\begin{array}{l}\text { livestock as alternative livelihood option as depicted in } \\
\text { the regression model in this study. } \\
\text { Thereafter, some of the innovative fishers may be se- } \\
\text { lected as Fishers' Friends who may develop linkage } \\
\text { with the Mukhiya of the Panchayat to facilitate the } \\
\text { development programmes. Among them those who can } \\
\text { communicate better may also be encouraged to initiate }\end{array}$} & \multicolumn{3}{|c|}{$\begin{array}{l}\text { Field School to transfer the aquaculture technologies } \\
\text { needed in wetland, such as, pen culture, rearing of fry, } \\
\text { hapa-breeding, etc. However, in wetland management, } \\
\text { conflict resolution is an important aspect too. To mini- } \\
\text { mize the conflict with farmers, the innovative fisher- } \\
\text { leaders should also select collaborative farmer-leaders. } \\
\text { Such farmers, in collaboration with elderly persons of }\end{array}$} \\
\hline
\end{tabular}


Table 4. Multiple regression model for the prediction of innovativeness of fishers

\begin{tabular}{lllll}
\hline & \multicolumn{3}{c}{ Model Summary } \\
\hline Model & R & R Square & Adjusted $\mathbf{R}^{\mathbf{2}}$ & Std. Error of the Estimate \\
\hline 1 & $.505^{\mathrm{a}}$ & .255 & .215 & 2.318
\end{tabular}

a. Predictors: (Constant), Livestock, Family type

ANOVA ${ }^{\text {b }}$

Model

$\begin{array}{llllll} & \text { Sum of Squares } & \text { df } & \text { Mean Square } & \text { F } & \text { Sig. } \\ \text { Regression } & 68.192 & 2 & 34.096 & 6.346 & .004^{\text {a }} \\ \text { Residual } & 198.783 & 37 & 5.373 & & \\ \text { Total } & 266.975 & 39 & & & \end{array}$

a. Predictors: (Constant), Livestock, Family type

b. Dependent Variable: Innovativeness

\section{Coefficients $^{\mathrm{a}}$}

\begin{tabular}{|c|c|c|c|c|c|c|}
\hline \multirow[t]{2}{*}{ Model } & & \multicolumn{2}{|c|}{$\begin{array}{l}\text { Unstandardized } \\
\text { Coefficients }\end{array}$} & $\begin{array}{l}\text { Standardized Co- } \\
\text { efficients }\end{array}$ & \multirow[t]{2}{*}{$\mathrm{t}$} & \multirow[t]{2}{*}{ Sig. } \\
\hline & & B & Std. Error & Beta & & \\
\hline 1 & (Constant) & 9.626 & 1.189 & & 8.099 & .000 \\
\hline & Family type & -1.463 & .878 & -.236 & -1.666 & .104 \\
\hline & Livestock & .856 & .278 & .437 & 3.079 & .004 \\
\hline
\end{tabular}

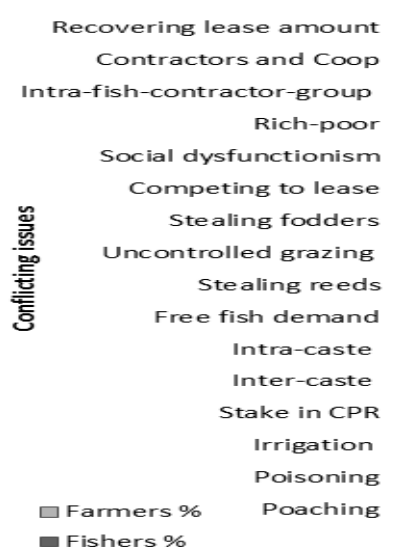

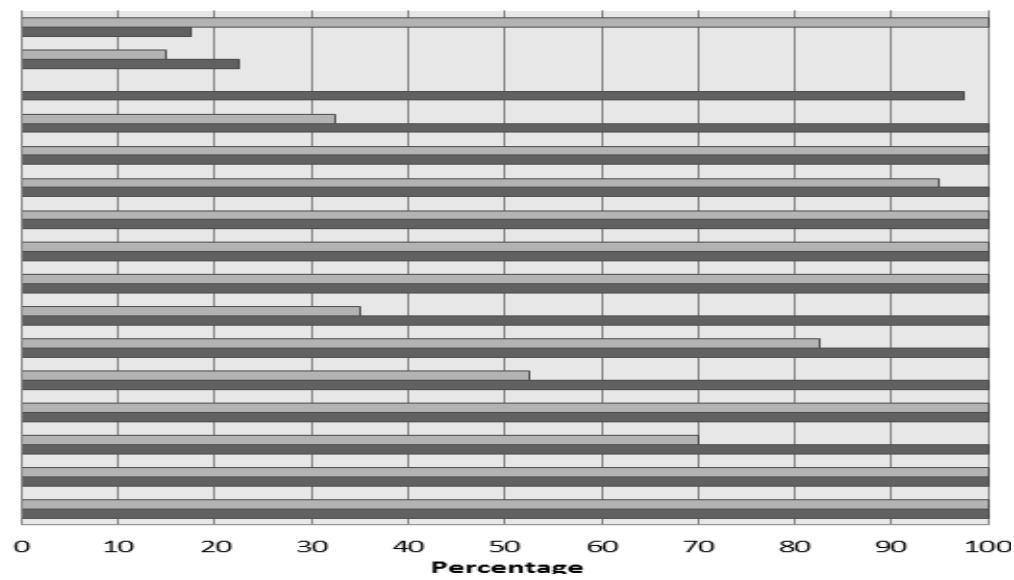

Fig. 1. Perception of the key informants about the conflicting issues raised by the fishers and farmers in terms of percentage.

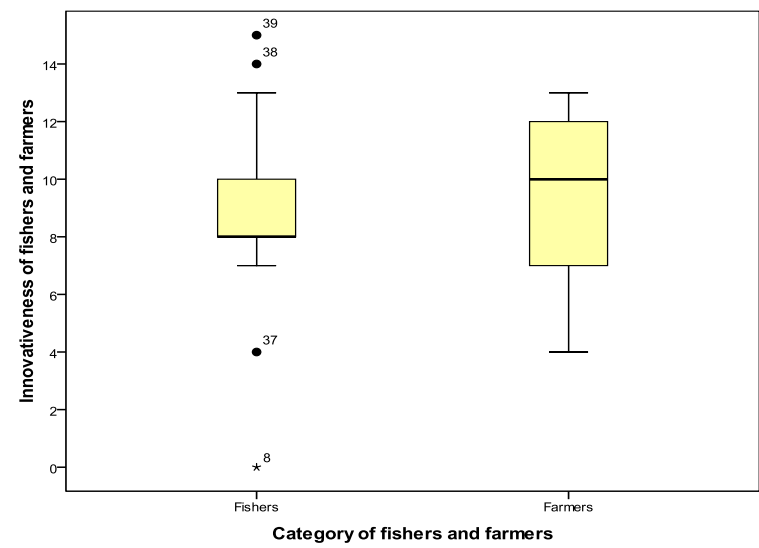

Fig. 2. Boxplot for innovativeness score of fishers and farmers. the village, may help in resolving conflicts. Moreover, the innovative fishers, the collaborative farmer-leader and preferred elderly persons may also act as mediators in the conflict resolution process. Consequently, the elderly mediators may learn about the legalities from Nyay Mitras (Legal Advisers) and Sarpanch in the Panchayat. Thereafter, innovative fisher-leaders and Fishers' Friends, in consultation with the collaborative farmer-leader and elderly mediators, may initiate training programmes on organizational and legal aspects of the Field School Programmes under the guidance of DoF and NGOs. Subsequently, they may also organize the fishers to initiate community based fisheries management. Furthermore, the technical training programmes on pen culture and stocking of larger fingerlings need to be enriched with associated development programmes and lessons learnt on the sharing of resources during flood. Accordingly, an empowered fisher community may ensure the sustainability of water resources and facilitate wise use of the wetland 


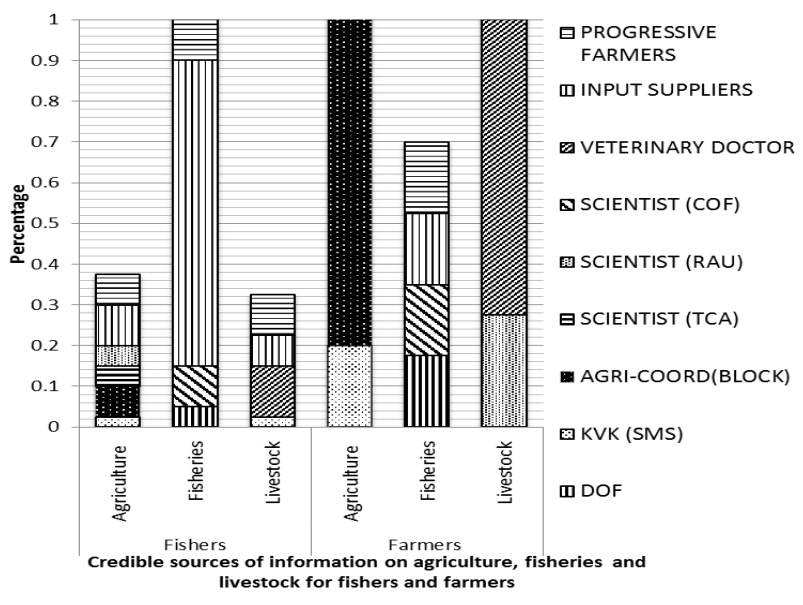

Fig. 3. Credibility of public, private and community extension services.

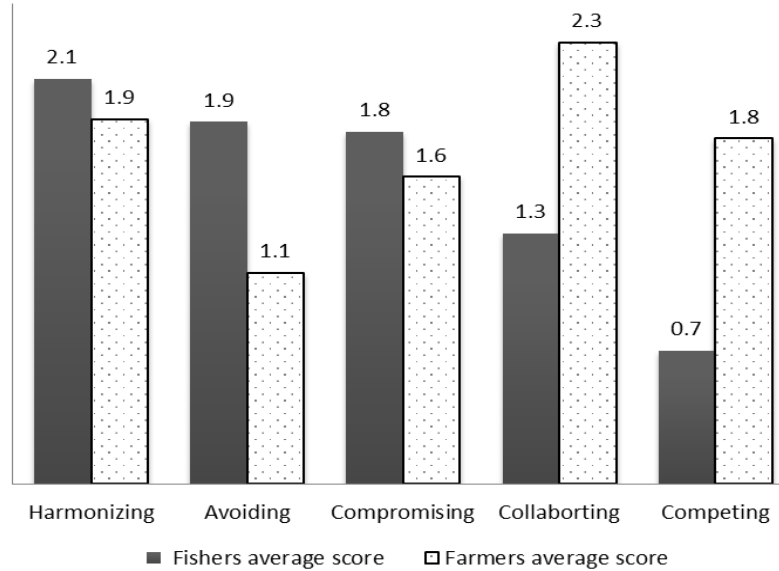

Fig. 4. Average score for conflict management style of fishers and farmers.

development.

Insights of key informants in managing conflict: $\mathrm{KI}$ investigations have been designated as a substitute to population-based studies in evaluating community (Muhit et al., 2007), for although they provided a very limited basis for quantification, they give an insight on sensitive issues related to conflicts. In the present study, the KIs revealed 16 types of issues that created conflicts in the identified wetland and helped in exploring novel ideas while formulating the conflict resolution strategies. They proposed the need of technology transfer in fisheries to keep the fishers more engaged so that they may be less involved in aggravating conflicts. This could be a novel idea as idle and unsafe people are likely to indulge in conflicts (Alika and Aibieyi, 2014).

Severity of wetland conflicts: Amongst the identified conflicts, several were observed to be severe enough for the fishers to be dragged to courts. Such stark conflicts were mostly related to the water bodies and were primarily affecting the fishers. These conflicts were due to poaching of fish and poisoning of water bodies.

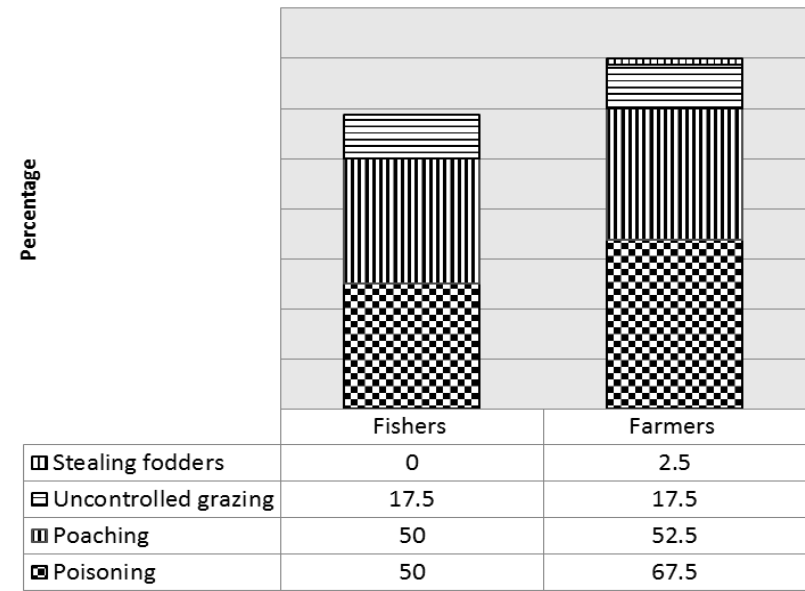

Fig 5: Perception of fishers and farmers resolving conflict through court in percentage

Therefore, fisheries extension programmes for wetlands have to incorporate conflict resolution mechanisms along with transfer of technology methods for fisheries. Numerous other studies have also emphasized similar conflicts in the wetlands which mainly revolve around issues like, resource sharing by fishers and farmers (Bhuiyan, 2013), competition, declining resources, urbanization and infrastructure development (Sebastiá-Frasquet et al., 2014), commercialization, landscape planning for empowered stakeholders, lack of property rights, conflicting conservation and livelihood approaches, conflict among line departments (Arsad, 2011), competition among fishers, conflict between the lease holder and the community and dearth of public awareness about the importance of wetlands (Wang et al., 2008).

Fisheries technology for wetlands: Impersonal conflicts foster innovation (Baqutayan, 2014). Therefore, as perceived by Rahman et al. (2010), if the technology transfer mechanism also incorporates conflict resolution process in such wetland fishery, it can facilitate pen culture and stocking of larger fingerlings.

Strengthening of the local conflict resolution mechanism: Wisdom of elderly persons needs to be recognized and they can be directly involved in the development initiatives (Tait, 2007). It was observed that fishers and farmers were approaching the elderly persons in the village to use their wisdom in resolving the conflicts. Therefore, local conflict resolution mechanism through Panchayats can be further strengthened by involving such elderly persons in the conflict resolution and development process.

A fisheries extension programme for wetlands: Though the reach of most public extension system remains inadequate (NSSO, 2005), fisheries extension services were observed to be still more pitiable in comparison. Moreover, although physical and chemical parameters were found to be suitable (Shweta and Srivastava, 2013), aquaculture practices were not adopted by the fishers of Balua wetland. Therefore, the 


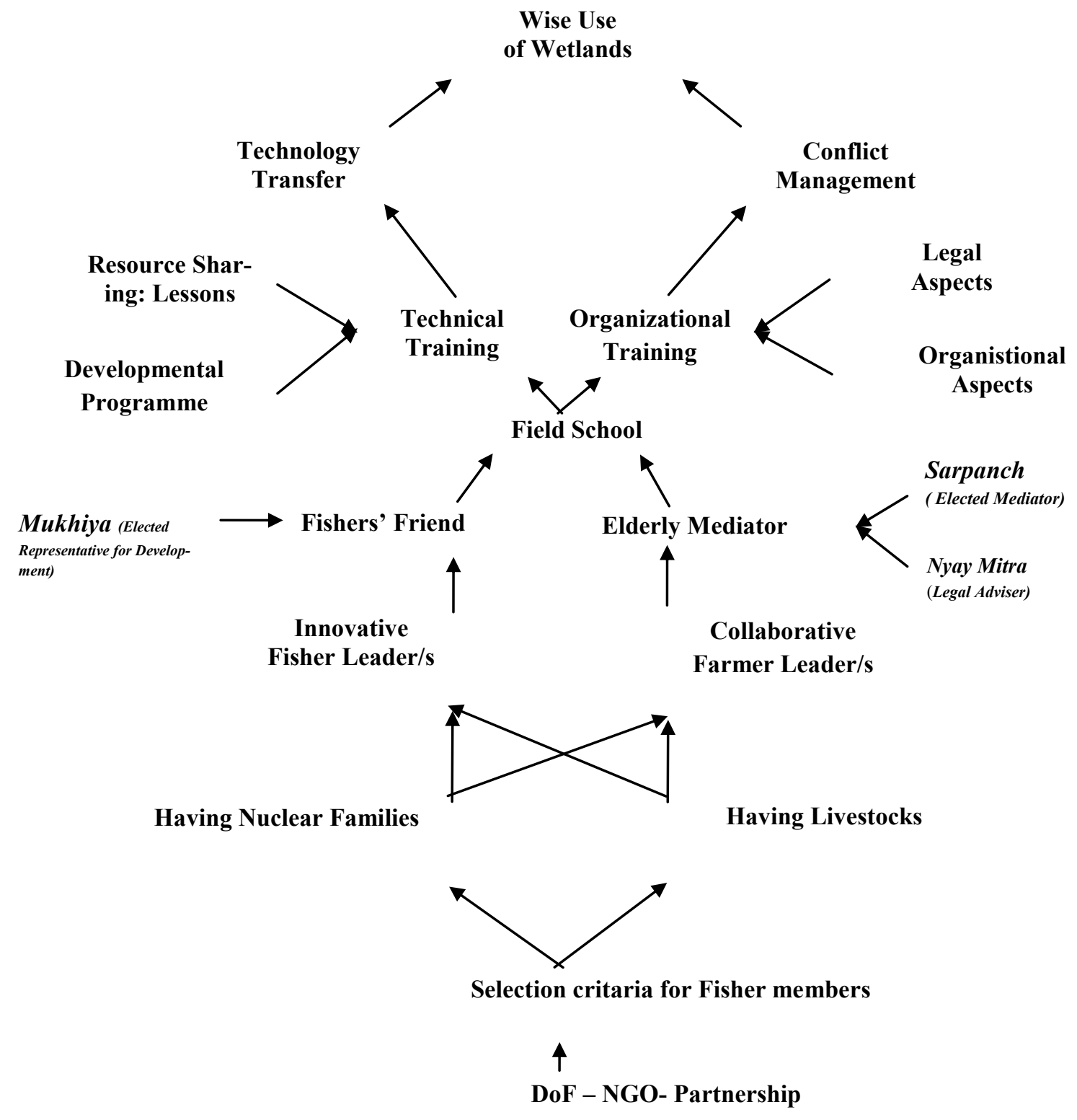

Fig 6: Peace and prosperity model for wise use of wetlands.

need to undertake urgent steps to establish customer services, at reduced cost, to boost access to quality information and extension-contact among the fisher folk of the area (Ifejika, 2013) could be sensed. Furthermore, fisheries extension service in that wetland can be strengthened by adopting the concept of participative approaches, such as, Farmers Friend and Fisher Field Schools, who could inform and train fishers on modern technologies and conflict resolution methods. Similarly, institutional reforms were earlier suggested in the form of power sharing between the state and stakeholders (Khan, 2011), encouraging local participation (Kothari, 2011), developing 'tailor fit approach' (Cunningham et al., 2011) and finally evolving an institutional structure to resolve such conflicts.

\section{Conclusion}

In the wetland (Balua Chaur) selected for this study, where families of around 110 fishers and nearby 150 farmers were residing, it was observed that socioeconomically the fishers were weaker than farmers. Furthermore, it was seen that although the fishers were innovative, public extension support to the fishers was far feebler when compared to similar support provided to the farming community. It was also observed that though local conflict resolution mechanisms existed in the villages, the irretrievable repercussion of the conflicts between the fishers and farmers manifested in further marginalizing the fishers. Therefore, there was a need to identify the socioeconomic factors and the conflict management styles of the fishers and farmers that could be factored with their innovativeness. Factor analysis to reduce and segregate the socioeconomic and psychological variables of the fishers that were associated with innovativeness and further analysis of 
ANOVA and regression showed that in case of fishers, two major groups of interrelated variables that accounted for $60.6 \%$ of the total variance were identified through this method. The factor 1 accounted for $34.8 \%$ of the total variance that included innovativeness, income, education, mass media exposure, extension contact, livestock ownership, land ownership, mobile use collaborating and competing style of conflict management and named as innovative factor. Factor 2 accounted for $25.8 \%$ of the total variance and reflected caste, age, family size, credit orientation, and family type and thus, factor 2 can be inferred as noninnovative characteristics of fishers. The ANOVA table and stepwise multiple regression model exhibited that the nuclear family type and livestock have significant impact on the innovativeness of fishers with $\mathrm{R}^{2}$ value 0.255 with significant $f$ value. It shows that nearly 25 percent variation in innovativeness of fishers was caused by nuclear family type and having livestock. Based on the findings a transcendent and an unequivocal fisheries extension model for wetlands are desired. The upshot of this study manifested into an innovative peace and prosperity model that can address the issues related to adoption of new technology and reinforce the local conflict resolution mechanisms and enhance the productivity of wetland in sustainable mode.

\section{ACKNOWLEDGEMENTS}

This study was accompanied with the fellowship of Indian Council of Agricultural Research, New Delhi, rooted through Central Institute of Fisheries Education (CIFE), Mumbai. Therefore, the authors acknowledge Dr. W.S. Lakra, Director, CIFE, for facilitating this work. The personnel of the College of Fisheries, Rajendra Agricultural University, Bihar are acknowledged for enabling collaboration for the identification of key informants, local representatives, fishers and farmers of the premeditated wetland.

\section{REFERENCES}

Alika, I.J., Aibieyi, S. (2014). Mechanism of Economic Empowerment and Development in Nigeria: A Discourse, An Inter. Jour. of Arts and Human., 3 (2): 137-157

Arsad, M. (2011). Management Plan Uchhali wetlands complex: a part of Salt Range Wetlands complex, The Ministry of Environment's Pakistan wetlands Programme.

Baqutayan, S.M.S. (2014). The Relationship between Conflict Management and Innovation Performance. Eur. Jour. of Bus. and Manag., 6: 90-95

Bhat, S.A., Meraj, G., Yaseen, S. and Pandit, A.K., (2014). Statistical assessment of water quality parameters for pollution source identification in Sukhnag stream: an inflow stream of lake Wular (Ramsar Site), Kashmir Himalaya. Jour. of Ecosys., 2014.

Bhuiyan, M.R. (2013). Wetland Management in Bangladesh; Nature study society of Bangladesh

Cunningham, E., Chassels, M., Fox, J. and Mustafa, M. (2011). Introduction: tailoring collaborative conserva- tion in Bangladesh. Rural Livelihood and Protected Landscapes: Co-management in the Wetlands and Forest of Bangladesh. USAID, Nishorgo Network, 204.

Hurt, H.T., Joseph, K., and Cook, C.D. (1977). Scales for the measurement of innovativeness. Hum. Com. Res., 4: 58-65.

Ifejika, P.I. (2013). Insight on How Fisherfolk Use Mobile Phone to Communicate in Fishing Communities of Kainji Lake Basin, Nigeria. Inter. Jour. of Info. and Com. Tech. Res., 3 (12): 316-322

Khan S.M.M.H. (2011). Participatory wetland resource governance in Bangladesh: an analysis of community-based experiments in Hakaluki haor: Clayton H. Riddell Faculty of Environment, Earth, and Resources, Natural Resources Institute, University of Manitoba.

Kothari, A. (2011). How not to save wetlands. Infochange Environment India.

Moore, Peter D. (2008). Wetlands: Revised Edition. Bang Hermitage (Facts on File, Inc.), New York. pp. 270

Muhit, M.A., Shah, S.P., Gilbert, C.E., Hartley, S.D. \& Foster, A. (2007). The key informant method: a novel means of ascertaining blind children in Bangladesh. Brit. Jour. of Ophth., 91: 995-999. doi: 10.1136/ bjo.2006.108027

NSSO (2005). Situation assessment survey of farmers: Access to modern technology for farming, 59th round (JanuaryDecember 2003). Report No. 499 (59/33/2). New Delhi: Ministry of Statistics and Programme Implementation.

Panini, D. (2007). The Ramsar Convention and National Laws and Policies for Wetlands in India. Technical Consultation on Designing Methodologies to Review Laws and Institutions Relevant to Wetlands.

Prasad, S.N. Ramchandra, T.V., Ahalya, N., Sengupta, T., Kumar,A, Tiwari, A.K., Vijayan, V.S. and Vijanyan, L., (2002). Conservation of wetlands of India - a review, Trop. Eco., 43 (1): 173-186.

Rahman, M.F., Benoy K. Barman, B.K., Van, M. and Dewan, S. (2010). Impacts of technological interventions on fish production and biodiversity of seasonal floodplains in Bangladesh, The WorldFish Center, CBFC Working Paper No. 1.

Ramsar Convention Secretariat, (2013). The Ramsar Convention Manual: a guide to the Convention on Wetlands (Ramsar, Iran, 1971), 6th ed. Ramsar Convention Secretariat, Gland, Switzerland.

Reginald. A., (2006). PhD, Elemental Truths. Retrieved on March, 172013 from http:// elementaltruths. blogspot.com/2006/11/conflict-management-quiz.html.

Sebastiá-frasquet, M.T., Altur, V. and Sanchis, J.A. (2014). Wetland Planning: Current Problems and Environmental Management Proposals at Supra-Municipal Scale (Spanish Mediterranean Coast). Wat., 6: 620-641.

Shweta and Srivastava S.J. (2013). Phytoplankton Diversity and Dynamics of Balua Floodplain Lake (Chaur), Muzaffarpur, Bihar, India - A Seasonal Study, Inter. Jour. of Aqu. Sci. and Tech., 1:1-8

Tait, P.L. (2007). Systems of Conflict Resolution within First Nations Communities: Honouring The Elders, Honouring The Knowledge, Research Paper for the National Centre for First Nations Governance: 1-22

Wang, Y., Yao, Y. and Ju, M. (2008). Wise use of wetlands: current state of protection and utilization of Chinese wetlands and recommendations for improvement. Env. Manag., 41: 793-808. 